\title{
PERILAKU SADARI REMAJA PUTRI MELALUI PENDIDIKAN KESEHATAN DI SMK 1 MUHAMMADIYAH LAMONGAN
}

\author{
Sulistiyowati \\ STIKES Muhammadiyah Lamongan, Jl. Raya Plalangan, Plosowahyu Lamongan \\ Email : sulisfaraz@gmail.com
}

\begin{abstract}
Breast cancer incidence is still very high; therefore SADARI would be more effective if it is done as early as possible to determine abnormalities. Health education is one effort to make adolescents realizing to do SADARI. The aim of this research is to analyze the impact of health education on breast self-examination behavior in female adolescent. Research design used is One-Group Pretest-Posttest design using simple random sampling obtaining sample of 49 female adolescents at SMK Muhammadiyah 1 Lamongan in April 2016. Data were collected using checklist with the observation method and analyzed using Chi-Square. The results showed that before being given health education, $93.9 \%$ of female adolescents made mistakes in doing SADARI and after being given health education, $69.4 \%$ of female adolescents made mistakes in doing SADARI. There are differences in doing SADARI of female adolescents in eleventh grade before and after being given health education concluded from this data $X^{2}=7,243$ and $p=0.007$. It can be concluded that the promotion of health education is very influential to improve SADARI in female adolescents. It can improve their knowledge and it can be applied in the examination and early detection of breast cancer.
\end{abstract}

Keywords: SADARI, female adolescents, health education

Abstrak : Kejadian kanker payudara masih sangat tinggi maka dari itu SADARI akan lebih efektif jika dilakukan sedini mungkin untuk mengetahui adanya kelainan. Pendidikan kesehatan merupakan salah satu upaya yang dapat dilakukan agar remaja melakukan SADARI.Tujuan penelitian untuk menganalisis pengaruh pendidikan kesehatan terhadap perilaku SADARI pada remaja putri. Desain penelitian yang digunakan adalah OneGroup Pretest-Postest Design, dengan menggunakan simple random Sampling diperoleh sampel sebesar 49 remaja putri di SMK Muhammadiyah 1 Lamongan pada bulan April 2016. Data menggunakan Cheklist dengan metode observasi. Dianalisis menggunakan ChiSquare. Hasil penelitian menunjukkan, sebelum diberikan pendidikan kesehatan 93,9\% perilaku SADARI salah, setelah diberikan $69,4 \%$ perilaku SADARI Salah. Ada perbedaan perilaku SADARI pada remaja putri kelas XI Sebelum dan sesudah diberikan pendidikan kesehatan dengan $X^{2}=7.243$ dan $p=0,007$. Dapat disimpulkan pemberian pendidikan kesehatan sangat berpengaruh dalam peningkatan perilaku SADARI pada remaja putri dapat meningkatakan pengetahuan dan diaplikasikan dalam pemeriksaan dan deteksi dini adanya kanker payudara.

Kata kunci : perilaku,SADARI, Remaja Putri, Pendidikan kesehatan. 


\section{PENDAHULUAN}

Kanker payudara merupakan penyebab kematian sebagian besar perempuan yang saat ini menduduki peringkat kedua setelah kanker leher rahim diantara kanker yang menyerang perempuan. Deteksi yang terlambat dan kurangnya informasi menyebabkan sebagian besar penderita kanker payudara terlambat diobati Selain itu kecenderungan peningkatan prevelensinya tidak dapat dihindari. Ditambah lagi kematian karena kanker payudara masih tinggi, terutama pada negara-negara sedang berkembang, karena keterlambatan diagnosis, yang berarti juga keterlambatan pengobatan (Bustan, 2007).

Pada dewasa ini sudah menunjukkan tren yang semakin banyak ditemukan penderita kanker payudara pada usia muda, bahkan tidak sedikit remaja putri usia empat belas tahun menderita tumor di payudaranya. Dimana tumor yang terjadi bisa menjadi kanker, bila tidak terdeteksi lebih awal. Meskipun tidak semuanya ganas, tetapi ini menunjukkan bahwa gejala kanker payudara yang semakin tinggi di usia remaja (Lily, 2008). Deteksi dini yaitu periksa payudara sendiri atau SADARI terbukti sangat efektif dapat menurunkan angka kematian dan kesakitan pada perempuan

Prevalensi kanker payudara di Indonesia adalah 109 per 100.000 penduduk yang sebagian besar adalah remaja. Masalah kanker payudara di Indonesia menjadi lebih besar karena lebih dari $70 \%$ penderita kanker payudara datang ke dokter pada stadium yang sudah lanjut. Pentingnya deteksi dini dengan periksa payudara sendiri atau SADARI dapat menurunkan angka kematian dan kesakitan dan dapat dilakukan dari awal pubertas. Studi pendahuluan yang dilakukan pada siswi kelas XI SMK 1 Muhammadiyah Lamongan menunjukkan $80 \%$ siswi belum pernah melakukan
SADARI. Banyak faktor yang melatarbelakangi remaja putri tidak melakukan SADARI diantaranya adalah pengetahuan, Pengetahuan merupakan aspek pokok untuk menentukan perilaku seseorang untuk menyadari dan tidak, maupun untuk mengatur perilakunya sendiri. (Soetriono, 2007.) Dengan pengetahuan yang baik diharapkan remaja putri mau melakukan SADARI dengan teknik yang benar dan secara teratur.

Salah satu upaya untuk meningkatkan pengetahuan remaja putrid sehingga mau melakukan SADARI adalah melalui pendidikan kesehatan seperti penyuluhan disekolah dan, informasi dari buku-buku kesehatan dan KIE tentang manfaat positif untuk melakukan SADARI

\section{METODE}

Penelitian ini menggunakan pretest-posttest one group design. Populasi dalam penelitian ini adalah Seluruh Remaja Putri kelas XI Di SMK 1 Muhammadiyah Lamongan Bulan April 2016, dengan menggunakan teksik simple random sampling diperoleh 49 sampel.

Variabel perilaku SADARI, Perlakuan Diberikan pendidikan kesehatan. Pengambilan data menggunakan Cheklist dengan metode observasi. Data dianalisis dengan uji statistik Chi-Square dengan tingkat kemaknaan $\alpha=0,05$.

\section{HASIL DAN PEMBAHASAN}

a. Hasil

a. Data Umum

1) Distribusi Umur Remaja Putri

Tabel 1. Distribusi Umur Remaja Putri kelas XI di SMK 1 Muhammadiyah Lamongan tahun 2016

\begin{tabular}{|c|c|c|c|}
\hline No & $\begin{array}{c}\text { Umur } \\
\text { Remaja }\end{array}$ & Frekuensi & $(\%)$ \\
\hline 1 & 14 tahun & 18 & 36,7 \\
\hline 2 & 15 tahun & 31 & 63,3 \\
\hline
\end{tabular}


Jumlah

49

100

Berdasarkan tabel 1 menunjukkan Lebih dari sebagian remaja putri berusia 15 tahun yaitu sebanyak 31 orang atau $63,3 \%$.

2) Distribusi Remaja Putri Berdasarkan Umur Ibu

Tabel 2. Distribusi umur Ibu Remaja Putri kelas XI di SMK 1 Muhammadiyah Lamongan tahun 2016

\begin{tabular}{|c|c|c|c|}
\hline No & $\begin{array}{c}\text { Umur } \\
\text { Orang Tua }\end{array}$ & Jumlah & $(\%)$ \\
\hline 1 & 20-30 Tahun & 20 & 40,8 \\
\hline 2 & 30-40 Tahun & 25 & 51,0 \\
\hline \multirow[t]{2}{*}{3} & >40 Tahun & 4 & 8,2 \\
\hline & Jumlah & 49 & 100 \\
\hline
\end{tabular}

Berdasarkan tabel 2 menunjukkan Lebih dari sebagian ibu remaja putri berumur 30-40 tahun yaitu sebanyak 25 orang atau 51,0\%, dan sebagian kecil remaja putri orang tuanya berumur lebih dari 40 tahun yaitu sebanyak 4 orang atau $8,2 \%$.

3) Distribusi Remaja Putri Berdasarkan Pendidikan Ibu

Tabel 3. Distribusi Pendidikan Ibu Remaja Putri kelas XI di SMK 1 Muhammadiyah Lamongan tahun 2016

\begin{tabular}{clcc}
\hline No & $\begin{array}{c}\text { Pendidikan } \\
\text { Ibu }\end{array}$ & Frekuensi & $(\boldsymbol{\%})$ \\
\hline 1. & SD & 30 & 61,2 \\
2. & SMP & 10 & 20,4 \\
3. & SMA & 5 & 10,2 \\
4. & PT/SARJANA & 4 & 8,2 \\
\multicolumn{2}{c}{ Jumlah } & $\mathbf{4 9}$ & $\mathbf{1 0 0}$ \\
\hline
\end{tabular}

Berdasarkan tabel 3 menunjukkan bahwa lebih dari sebagian Ibu Remaja putri tingkat pendidikannya adalah SD yaitu sebanyak 30 orang atau 61,2\%, dan sebagian kecil ibu Remaja Putri tingkat pendidikannya adalah PT atau Serjana yaitu sebanyak 4 orang atau 8,2\%.
4) Distribusi Remaja Putri Berdasarkan Pekerjaan Ibu

Tabel 4. Distribusi Pekerjaan Ibu Remaja Putri kelas XI di SMK 1 Muhammadiyah Lamongan tahun 2016

\begin{tabular}{c|l|c|c}
\hline No & $\begin{array}{c}\text { Pekerjaan } \\
\text { Ibu }\end{array}$ & Frekuensi & $(\%)$ \\
\hline 1. & Ibu & 15 & 30,6 \\
& Rumah & & \\
& Tangga & & \\
2. & Petani & 25 & 51,0 \\
3. & Swasta & 5 & 10,2 \\
4. & PNS & 4 & 8,2 \\
\hline & Jumlah & $\mathbf{4 9}$ & $\mathbf{1 0 0}$ \\
\hline
\end{tabular}

Berdasarkan tabel 4 tersebut menunjukkan bahwa lebih dari sebagian Ibu Remaja Putri bekerja sebagai Petani yaitu sebanyak 25 orang atau 51,0\%, dan sebagian kecil Ibu Remaja putri Bekerja Sebagai PNS yaitu sebanyak 4 orang atau $8,2 \%$.

5) Distribusi Remaja Putri Berdasarkan Jumlah Saudara Perempuan

Tabel 5.Distribusi Jumlah Saudara Perempuan Remaja Putri kelas XI di SMK 1 Muhammadiyah Lamongan tahun 2016

\begin{tabular}{|c|c|c|c|}
\hline No & $\begin{array}{c}\text { Jumlah } \\
\text { Saudara } \\
\text { perempuan }\end{array}$ & Frekuensi & $(\%)$ \\
\hline 1 & $\begin{array}{l}\text { Tidak } \\
\text { mempunyai } \\
\text { saudara } \\
\text { perempuan }\end{array}$ & 26 & 53,1 \\
\hline 2 & $\begin{array}{l}1 \text { saudara } \\
\text { perempuan. }\end{array}$ & 14 & 28,6 \\
\hline \multirow[t]{2}{*}{3} & $\begin{array}{l}>1 \text { saudara } \\
\text { perempuan. }\end{array}$ & 9 & 18,4 \\
\hline & Jumlah & 49 & 100 \\
\hline
\end{tabular}

bahwa Lebih dari sebagian Remaja putri tidak mempunyai saudara perempuan yaitu sebanyak 26 orang atau 53,1\%, dan sebagian kecil remaja putri mempunyai saudara perempuan lebih dari 1 saudara perempuan yaitu 9 orang atau 18,4\% 
b. Data Khusus

1) Perilaku SADARI pada remaja putri sebelum pemberian pendidikan Kesehatan

Tabel 6 Distribusi Perilaku SADARI Remaja Putri Kelas XI Sebelum Pemberian Pendidikan Kesehatan Di SMK 1 Muhammadiyah LamonganTahun 2016

\begin{tabular}{cccc}
\hline No & $\begin{array}{c}\text { Perilaku } \\
\text { SADARI }\end{array}$ & Frekuensi & $\mathbf{( \% )}$ \\
1 & SADARI Benar & 3 & 6,1 \\
2 & SADARI Salah & 46 & 93,9 \\
\hline & Jumlah & $\mathbf{4 9}$ & $\mathbf{1 0 0}$ \\
\hline
\end{tabular}

Berdasarkan tabel 6 menunjukkan bahwa dari 49 remaja putri, hampir seluruh perilaku SADARI salah yaitu sebanyak 46 Remaja Putri atau 93,9\%.

2) Perilaku SADARI remaja putri sesudah pemberian pendidikan kesehatan

Tabel 7 Distribusi Perilaku SADARI Pada Remaja Putri Kelas XI Sesudah Pemberian Pendidikan KesehatanDi SMK 1 Muhammadiyah Lamongan Tahun 2016.

\begin{tabular}{c|c|c|c}
\hline No & $\begin{array}{c}\text { Perilaku } \\
\text { SADARI }\end{array}$ & Frekuensi & $\mathbf{( \% )}$ \\
\hline 1 & SADARI Benar & 15 & 30,6 \\
2 & SADARI Salah & 34 & 69,4 \\
& Jumlah & 49 & $\mathbf{1 0 0}$ \\
\hline
\end{tabular}

Berdasarkan tabel 7 menunjukkan bahwa dari 49 remaja putri, Lebih dari sebagian perilaku SADARI salah yaitu sebanyak 34 remaja putri atau $69,4 \%$.

3) Perbedaan perilaku SADARI Pada remaja Putri Sebelum dan sesudah pemberian Pendidikan Kesehatan

Tabel 8 Tabel silang perilaku SADARI Pada remaja Putri Sebelum dan sesudah Diberikan Pendidikan Kesehatan Di SMK 1 Muhammadiyah Lamongann Kabuapaten Lamongan Tahun 2016.

Perilaku Perilaku SADARI Jumlah

\begin{tabular}{cccc}
\hline SADARI & \multicolumn{2}{c}{ sesudah } & \\
\cline { 2 - 3 } sebelum & $\begin{array}{c}\text { SADARI } \\
\text { Benar }\end{array}$ & $\begin{array}{c}\text { SADARI } \\
\text { Salah }\end{array}$ \\
\hline SADARI & 3 & 0 & 3 \\
Benar & $(100 \%)$ & $(0 \%)$ & $(100 \%)$ \\
SADARI & 12 & 34 & 46 \\
Salah & $(31,3 \%$ & $(68,7 \%)$ & $(100 \%)$ \\
Jumlah & 15 & 34 & 49 \\
Nilai X $\mathbf{X}^{2} \mathbf{~}$ & $(30,6 \%)$ & $(69,4 \%)$ & $(100 \%)$ \\
\hline
\end{tabular}

Berdasarkan tabel 8 menunjukkan bahwa dari 3 remaja putri yang melakukan SADARI Benar sebelum diberikan pendidikan kesehatan, seluruhnya atau 100\% melakukan SADARI Benar setelah diberikan pendidikan kesehatan. Dan dari 46 remaja putri yang melakukan SADARI Salah sebelum diberikan pendidikan kesehatan, lebih dari sebagian atau $68,7 \%$ perilaku SADARI Salah setelah diberikan pendidikan kesehatan.

Berdasarkan Hasil Uji Chi Square $\left(X^{2}\right)$ didapatkan nilai signifikan $(\mathrm{p})$ sebesar 0,007 yang berarti dibawah nilai batas standar signifikan yang sebesar $\alpha$ 0,05, sehingga $\mathrm{H}_{0}$ Ditolak dan $\mathrm{H}_{1}$ diterima, artinya ada pengaruh pendidikan kesehatan terhadap perilaku SADARI Pada Remaja Putri Kelas XI Di SMK 1 Muhammadiyah Lamongan Kabupaten Lamongan tahun 2016.

\section{b. Pembahasan \\ Perilaku SADARI Pada remaja putri kelas Sebelum Diberikan Pendidikan Kesehatan.}

Berdasarkan tabel 6 tersebut diatas dapat disimpulkan bahwa dari 49 Remaja Putri, Hampir seluruhnya atau 93,9\% perilaku SADARI salah. Karena kurangnya memperoleh informasi yang bisa dipengaruhi dari Pekerjaan orang tua, pendidikan orang tua dan jumlah saudara perempuan.

Berdasarkan tabel 4 menunjukkan bahwa lebih dari sebagian atau 51,0\% Ibu 
remaja putri bekerja sebagai Petani. Pekerjaan orang tua terutama ibu sangat berpengaruh terhadap informasi-informasi yang diberikan kepada anaknya apalagi jika ibu bekerja sebagai Petani, dimana pekerjaan tersebut merupakan pekerjaan yang melelahkan dan cukup menguras tenaga demi tuntutan ekonomi yang semakin tinggi sehingga pengetahuan dan pengalaman sangat sulit didapatkan oleh remaja putri tentang deteksi dini kanker payudara dengan cara SADARI. Menurut Wahid Iqbal Mubarrak (2007) bahwa lingkungan pekerjaan dapat menjadikan seseorang memperoleh suatu pengalaman dan pengetahuan baik secara langsung maupun tidak langsung.

Faktor lainnya adalah pendidikan Ibu , Berdasarkan tabel 3 tersebut menunjukkan bahwa lebih dari sebagian atau 61,2\% ibu Remaja putri tingkat pendidikannya adalah SD. SD merupakan pendidikan yang paling dasar yang mana pengetahuan dan pengalaman seseorang masih belum cukup banyak dan informasi yang diperoleh sangat sulit sehingga ibu tidak dapat memberikan informasi yang jelas tentang SADARI. Seseorang yang berpendidikan lebih rendah kemungkinan akan lebih sulit untuk menerima informasi dan yang berpendidikan lebih tinggi tidak akan mengalami kesulitan dalam menerima informasi. (Herman, 2009). Jumlah saudara perempuan juga mempengaruhi perilaku SADARI Berdasarkan tabel 5 menunjukkan bahwa lebih dari sebagian atau 53,1\% Remaja putri tidak mempunyai saudara perempuan. Remaja putri akan merasa dirinya nyaman jika ada lawan jenis yang bisa dijadikan tempat untuk berbagi dan bercerita, karena hal itulah remaja akan lebih peka terhadap informasi yang diperoleh dan pengalaman yang sudah didapatkan saudara perempuannya dalam hal ini perilaku SADARI. Menurut Notoatmodjo (2007) pengalaman adalah reaksi atau respon yang terbuka dari seseorang terhadap suatu stimulus atau obyek yang memotivasi seseorang untuk memperoleh informasi dan berbuat sesuatu sehingga dapat menjaga dirinya menjadi lebih sehat dan membentuk kebiasaan yang menguntungkan kesehatan.

\section{Perilaku SADARI Pada Remaja Putri kelas Sesudah Diberikan Pendidikan Kesehatan.}

Berdasarkan tabel 7 menunjukkan bahwa dari 49 Remaja Putri Lebih dari sebagian atau $69,4 \%$ perilaku SADARI salah, terjadi penurunan kesalahan dalam perilaku SADARI sebelum dan sesudah pemberian pendidikan kesehatan . Hal ini kemungkinan dipengaruhi oleh faktor Umur Ibu dan umur remaja putri.

Berdasarkan tabel 2 menunjukkan Lebih dari sebagian atau 51,0\% ibu remaja putri berumur 30-40 tahun. Umur ibu tergolong dewasa pertengahan sehingga kemampuan berfikir lebih matang, informasi yang diterima terutama SADARI akan lebih dapat diaplikasikan sendiri dan bias memberikan pengetahuan untuk orang lain dalam hal ini remaja putri. Menurut Wahid Iqbal Mubarok (2007) bertambahnya umur seseorang pada aspek psikologis taraf berpikir seseorang akan semakin matang dan dewasa. Hal ini juga dipertegas oleh Nursalam (2008) Umur adalah usia individu yang terhitung mulai saat dilahirkan sampai saat beberapa tahun. Semakin cukup umur, tingkat kematangan seseorang akan lebih matang dalam berfikir dan bekerja. Dari segi kepercayaan masyarakat, seseorang yang lebih dewasa akan lebih dipercaya dari orang yang belum cukup kedewasaannya

Faktor lainnya adalah usia remaja putrid Berdasarkan tabel 1 menunjukkan Lebih dari sebagian atau $63,1 \%$ remaja Putri berumur 15 tahun, dimana usia 
tersebut masuk dalam kategori remaja pertengahan yang rasa tahunya tinggi terutama dalam hal reproduksi dan mencari tahu setiap perubahan yang terjadi terhadap dirinya sejak terjadi pubertas.Karena rasa tahu remaja sangat tinggi maka ketika diperikan informasi anakn lebih antusias dan mencari tahu penyebab dan sebisa mungkin mengaplikasikannya dalam kehidupan, tetapi remaja juga mempunyai sifat egoisme yang tinggi yang tidak mau kalah dengan temanya. Menurut Wahid Iqbal Mubarrak ( 2007) bahwa pada usia remaja akhir akan mengalami perubahan aspek psikologis seperti ego yang tinggi, persaan yang sensitif. Sehingga dengan adanya pendidikan kesehatan ini remaja berlomba untuk menampilkan hasil yang terbaik dalam hal ini melakukan SADARI

\section{Perilaku SADARI Remaja putri Sebelum dan Sesudah diberikan Pendidikan Kesehatan}

Dari hasil uji statistik menunjukkan pemberian pendidikan kesehatan tentang SADARI dapat berpengaruh pada perilaku SADARI Hal ini dapat dilihat dari tabel yang telah diuraikan diatas.Berdasarkan tabel 8 tersebut menunjukkan bahwa dari 46 remaja putri yang melakukan SADARI Salah sebelum diberikan pendidikan kesehatan lebih dari sebagian atau 68,7\% perilaku SADARI Salah setelah diberikan pendidikan kesehatan. Ini artinya terjadi penurunan prosentase kesalahan dalam melakukan SADARI.

$\begin{array}{lr}\text { Berdasarkan hasil uji } & \text { Chi-Square } \\ \left(X^{2}\right) \text { menunjukkan bahwa pemberian } \\ \text { pendidikan kesehatan }\end{array}$
mempengaruhi perubahan perilaku secara signifikan. Hasil pengujian dengan uji Chi-Square $\left(X^{2}\right)$ pada perubahan perilaku $X^{2}=7.243$ danp $=0,007$ dimana $\alpha<0,05$ maka $\mathrm{H}_{0}$ ditolak dan $\mathrm{H}_{1}$ diterima artinya ada perbedaan perilaku SADARI Pada Remaja Putri Kelas XI Sebelum dan
Sesudah Diberikan Pendidikan Kesehatan Di SMK 1 Muhammadiyah Lamongan Kabupaten Lamongan.

Perilaku SADARI memang sangat penting bagi kehidupan apalagi jika perilaku yang tadinya salah dapat dirubah menjadi benar. Perubahan terjadi saat sudah mengatahui atau mendapatkan pendidikan kesehatan tentang pentingnya SADARI Untuk deteksi dini adanya kanker ataupun kanker payudara, dimana dapat memberikan dampak yang baik untuk manusia agar terhindar dari penyakit yang mematikan seperti tumor dan kanker payudara.

Perilaku kesehatan pada dasarnya adalah respon seseorang atau organisme terhadap stimulus yang berkaitan dengan sakit dan penyakit, sistem pelayanan kesehatan, makanan, serta lingkungan. Dalam aspek biologis perilaku adalah suatu kegiatan atau aktifitas organisme atau mahluk hidup bersangkutan (Notoatmodjo, 2007). Sedangkan SADARI adalah pemeriksaan payudara sendiri yang dilakukan sebagai deteksi dini kanker payudara. (Dalimartha, 2006).

Dari penelitian yang dilakukan oleh Ria Nistia Ningrum (2012) di SMKN 1 Negeri Bidegan Jawa Timur terhadap 10 siswi didapatkan 2 siswi melakukan SADARI tetapi tidak teratur setiap bulannya dan 8 siswi belum pernah melakukan SADARI. Hal ini disebabkan masih kurangnya kesadaran perempuan khususnya remaja dalam mendeteksi secara dini terjadinya kanker payudara dengan cara memeriksa payudara sendiri atau SADARI.

Kesimpulan dalam penelitian ini bahwa dengan pemberian pendidikan kesehatan tentang SADARI memberikan dampak positif bagiremaja putri, pengalaman serta pengetahuan dalam menangani deteksi dini Kanker payudara, 
serta dapat merubah perilaku yang tadinya salah sehingga menjadi Benar.

\section{KESIMPULAN}

\section{Kesimpulan}

(1) Hampir Seluruh perilaku SADARI Pada remaja putri kelas XI salah sebelum diberikan pendidikan kesehatan Di SMK 1 Muhammadiyah Lamongan Kabupaten Lamongan.

(2) Lebih dari sebagian perilaku SADARI Pada remaja putri kelas XI Salah sesudah diberikan pendidikan kesehatan Di SMK 1 Muhammadiyah Lamongan Kabupaten Lamongan.

(3) Terdapat pengaruh pendidikan kesehatan terhadap Perilaku SADARI Pada remaja Putri kelas XI Di SMK 1 Muhammadiyah Lamongan Kabupaten Lamongan

\section{Saran}

sebagai sarana pembanding bagi dunia ilmu pengetahuan dalam memperkaya informasi tentang perilaku SADARI perlu dilakukan penelitian dengan menggunakan metode yang lain yang lebih menggali keaktifan responden.

\section{DAFTAR PUSTAKA}

Bustam. 2007. Kanker payudara. Jakarta:EGC

Dalimartha. 2004. Pengertian SADARI. www.SADARI.com, diakses tanggal 21 Januari 2016.

Helen Varney. 2006. Buku Ajar Asuhan Kebidanan: volume 1. Jakarta: EGC

Herman. 2009. Tingkatan pendidikan. Jakarta. EGC

Lily. 2008. Kesehatan reproduksi: Yogyakarta. Citra Medika

Niken. 2012. Perilaku SADARI Pada Remaja. Jakarta: EGC.
Notoatmodjo S . 2007. Pendidikan dan Perilaku Kesehatan. Jakarta: Rineka Cipta

Nursalam. 2008. Konsep dan Penerapan Metodologi Penelitian Ilmu Keperawatan. Jakrta: Salemba Medika

Putri, Naura .2009. Deteksi Dini Kanker Payudara. Yogyakarta: Aura Media

Ria Nistia Ningrum. 2012. Hubungan tingkat pengetahuan remaja putri dengan keteraturan melakukan SADARI Di SMK 1 Muhammadiyah Gresik: Stikes Muhammadiyah Lamongan

Riwidikdo. 2010. Definisi Perilaku. Jakarta: Prestasi Pustaka

Wahid Iqbal Mubarrak 1. 2007. Motifasi remaja dalam melakukan SADARI. Jakarta. EGC

Wahid Iqbal Mubarrak 2. 2007. Tingkatan umur pada remaja. Jakarta. EGC

Widyastuti. 2009, Ciri-ciri perkembangan remaja. Jakarta : EGC 